DOI https://doi.org/10.30525/978-9934-26-040-7-22

\title{
АКТУАЛЬНІ ПИТАННЯ МІСЦЯ ПОПЕРЕДНЬОГО ДОГОВОРУ В ЦИВІЛЬНОМУ ПРАВІ УКРАЇНИ
}

\author{
Можайкіна О. С. \\ кандидат психологічних наук, дочент, \\ доцент кафедри міжнародного, цивільного та комерційного права \\ Київського національного торговельно-економічного університету
}

Кононець О. М.

кандидат юридичних наук,

доцент кафедри міжнародного, цивільного та комерційного права Київського національного торговельно-економічного університету м. Київ, Україна

Основою багатьох цивільних правовідносин $є$ різні за змістом і характером договори, які мають на меті встановлення, зміну або припинення прав і обов'язків їх сторін. Різноманітність соціальних зв'язків у цивільно-правовій діяльності суспільства вимагає наявності широкого спектру правових механізмів та правових інструментів для кожного конкретного інституту правовідносин.

Інститут попереднього договору має велику історію. Римське право («раctum de contrahendo») містило детальні норми, які регламентували застосування попереднього договору. Багато із цих норм увійшли до континентального права і лише у XX столітті зазнали значних змін.

Актуальність даної теми дослідження обумовлена центральним місцем договору у регулюванні майнового обігу, а також тим, що попередні договори все частіше використовуються суб'єктами цивільного та господарського права у практиці встановлення обов'язків щодо укладення в подальшому цивільно-правових договорів певного виду.

В практиці може скластися ситуації, коли укладення певного договору на даний момент $\epsilon$ недоречним 3 певних обставин або недоцільним, хоча в майбутньому такий договір був би вигідним усім сторонам або хоча б одній із них. При цьому сторони заінтересовані у певних гарантіях належного виконання зобов'язань іншою стороною.

Відтак, з впевненістю можна стверджувати, що по мірі розвитку i ускладнення суспільних відносин прийняттю на себе сторонами конкретних зобов'язань по передачі товарів, виконанню робіт, наданню 
послуг, все частіше передує етап узгодження умов майбутнього договору і проведення певних підготовчих дій.

Одним 3 правових інструментів, який дозволяє сторонам закріпити досягнуті домовленості і забезпечити укладення запланованого договору виступає попередній договір. Схожу позицію висловив О.М. Клименко, який висновує, що попередній договір є договірною конструкцією особливого виду, правовим інститутом, норми якого опосередковують відносно відособлене коло відносин щодо укладення в майбутньому основних договорів. Автор наголошує, що одним із основних завдань зазначеного договору є забезпечення (стабілізація) відносин між сторонами до укладення основного договору, гарантування реальної можливості через певний час набути відповідні права на тих самих умовах, які існували в момент укладення попереднього договору, навіть у тому разі, коли одна із сторін втратить інтерес до цих правовідносин [1, с. 8].

Цивільний кодекс УРСР (1963 р.) взагалі не визначав таку правову конструкцію як попередній договір. Виходячи із законодавчого визначення, яке міститься в Цивільному кодексі України (далі - ЦКУ), попереднім є договір, сторони якого зобов'язуються протягом певного строку (у певний термін) укласти договір в майбутньому (основний договір) на умовах, встановлених попереднім договором (ч. 1, ст. 635 ЦКУ) [2]. Варто звернути увагу, що законодавче закріплення попереднього договору також міститься у ст. 182 Господарського кодексу України (далі - ГКУ), в якій зазначено, що за попереднім договором суб' єкт господарювання зобов'язується у певний строк, але не пізніше одного року з моменту укладення попереднього договору, укласти основний господарський договір на умовах, передбачених попереднім договором [3].

Варто наголосити, що попередній договір $є$ універсальним інструментом, оскільки дозволяє поєднати сторони на майбутнє у зв'язку із укладенням багатьох різноманітних договорів. Аналіз української правозастосовної практики дозволяе висновувати, що попередній договір користується попитом як у споживчій сфері: при відчужені нерухомого та рухомого майна, так і в підприємницькій: при створенні товариства, відчуженні частки в статутному капіталі, передачі в оренду приміщень, обладнання тощо.

В науці цивільного та господарського права попередній договір займає особливе місце в класифікації договорів, оскільки вимагає спеціального режиму, який стосується певного кола відносин щодо укладення майбутніх основних договорів. Попередній договір не $є$ інструментом прямого впливу в цивільному та господарському обороті, 94 
це свого роду організаційний договір, який регулює укладення окремих видів договорів.

Особливістю попереднього договору $є$ те, що виконання умов такого договору не пов'язано з виконанням майнових вимог. Єдиним обов'язком, який виникає 3 попереднього договору, $\epsilon$ обов'язок укладення основного договору. В ситуації, коли відмова однієї із сторін від укладення основного договору тягне за собою збитки від неукладення основного договору для іншої сторони, виникає питання про допустимість укладення основного договору в примусовому порядку. ч. 3, ст. 635 ЦКУ 3 цього приводу визначає лише, що сторона, яка необгрунтовано ухиляється від укладення договору, передбаченого попереднім договором, повинна відшкодувати другій стороні збитки, завдані простроченням, якщо інше не встановлено попереднім договором або актами цивільного законодавства [2]. 3 цього випливає, що зазначена норма $\epsilon$ диспозитивною за своїм характером і сторони самостійно можуть встановлювати рівень відповідальності. Поряд 3 цим варто звернути увагу, що норми ГКУ є більш жорсткими. Так У ч. 3 ст. 182 ГКУ регламентовано, що у разі якщо сторона, яка уклала попередній договір, одержавши проект договору від іншої сторони, ухиляється від укладення основного договору, друга сторона має право вимагати укладення такого договору в судовому порядку [3]. Однак, є питання щодо того чи не буде у такому разі порушено один із основних принципів договірного права - принцип свободи договору, оскільки особа, яка буде вимагати укладення основного договору, обмежує свободу вибору іншої особи, при цьому вимагає певної майнової або матеріальної винагороди за відмову від укладення договору.

Варто також зауважити, що відповідно до законодавчих вимог попередній договір повинен містити умови, які будуть визначені в подальшому в основному договорі. В першу чергу мова йде про такі умови як предмет договору, ціна, строки. Наприклад, якщо за умовами майбутнього договору сторона бере на себе обов'язок продати іншій стороні індивідуально-визначену річ, то попередній договір повинен містити умову щодо ідентифікації такої речі на момент укладення основного договору. В той же час вважаємо, що відсутність у попередньому договорі окремих істотних умов основного договору ще не свідчить про його неукладеність або недійсність. Наприклад, якщо у попередньому договорі визначено приміщення, яке буде передано в оренду, але не встановлено розмір орендної плати, то такий попередній договір вважається укладеним. Ті умови, які не визначені у попередньому договорі можуть бути додатково узгоджені сторонами під час укладення основного договору. 
Підсумовуючи викладене вище, можна зробити висновок, що попередній та основний договори необхідно розглядати тільки у їхній єдності з точки зору тих наслідків, на які спрямовані інтереси суб'єктів цивільного та господарського права. В цьому розумінні попередній договір не $\epsilon$ самостійною угодою, а $\epsilon$ угодою, яка знаходиться у тісному взаємозв'язку з основним договором. Попередній договір при такому розумінні $є$ частиною переддоговірної стадії укладення основного договору. Визначення попереднього як організаційного дозволяє зробити висновок, що з попереднього договору не виникають певні майнові зобов'язання, однак виникає інший правовий наслідок пов'язаність контрагентів обов'язком укласти основний договір.

\section{Література:}

1. Клименко О.М. Попередній договір в цивільних відносинах: теорія і практика: автореф. дис. ... канд. юрид. наук: 12.00.03. Київ, 2010. $20 \mathrm{c}$.

2. Цивільний кодекс України: Закон України від 16.03.2003 р. №435-IV / Верховна Рада України. URL: https://zakon.rada.gov.ua/ laws/show/435-15\#Text (дата звернення 03.02.2021 p.).

3. Господарський кодекс України: Закон України від 16.01.2003 p. №436-IV / Верховна Рада України. URL: https://zakon.rada.gov.ua/ laws/show/436-15\#Text (дата звернення 03.02.2021р.).

DOI https://doi.org/10.30525/978-9934-26-040-7-23

\section{СКАСУВАННЯ РІШЕННЯ СУДУ ПРО ВИЗНАННЯ ФІЗИЧНОЇ ОСОБИ НЕДІЕЗДАТНОЮ}

\section{Татулич І. Ю.}

кандидат юридичних наук,

доцент кафедри процесуального права юридичного факультету

Чернівецького національного університету імені Юрія Федьковича м. Чернівиі, Украӥна

У зв'язку з внесеними змінами до процесуального законодавства (2017 р.) істотно зазнали змін справи, що стосуються зміни правового стану фізичної особи, а саме розгляд судом справ про обмеження 